Warm up

\title{
All cracked up
}

\section{P McCrory}

O ne hobby of mine is knuckle cracking. I don't know why I do this. Perhaps some American TV show set a bad role model for me at a vulnerable age. Certainly I have had my fair share of criticism over the years on this point. Not least from my mother.

There is a myth or old wives tale that osteoarthritis of the fingers is a certain future for us knuckle crackers. I was therefore pleased to read recently of several studies on this very topic suggesting that things are not as bad as they are cracked up to be. Excuse the bad pun!

A paper by Daniel Unger, who clearly had similar thoughts, impressed me. ${ }^{1} \mathrm{He}$ had cracked the knuckles of his left hand only (never the right) for 50 years. He then compared the degree of arthritis in his left and right hands and concluded that there was no difference. Well done I say. Who says an $\mathrm{N}=1$ study never gets published!

It turns out that there are two separate noises when a knuckle cracks. When the finger is pulled to crack the joint, the joint space is enlarged and the intraarticular pressure drops. A bubble of carbon dioxide then forms making a popping sound. When the bubble forms, the collateral ligaments are snapped back to their original position resulting in a second sound. The energy needed to perform all this is about $7 \%$ of what is needed to damage articular cartilage.

The absence of significant osteoarthritis has been confirmed by larger studies, and, apart from joints that were more swollen, no long term structural injury to the finger joints was evident. Interestingly, these studies also found that the grip strength of knuckle crackers' hands was weaker, although no mechanism for this was elucidated. ${ }^{23}$

So sleep easy all you knuckle crackers. Perhaps it's just as well that we won't get osteoarthritis of the hands else we may have a tough time opening the antiinflammatory medicine bottle!

Br J Sports Med 2003;37:377

\section{REFERENCES}

1 Unger D. Does knuckle cracking lead to osteoarthritis of the fingers? Arthritis Rheum 1998;41:949-50.

2 Simkin P. Habitual knuckle cracking and hand function. Ann Rheum Dis 1990:49:308-9.

3 Swezey R, Swezey S. The consequences of habitual knuckle cracking. West J Med $1975 ; 122: 377-9$.

\section{Group email for BASEM members}

Following the last Executive meeting, it was decided that the Communications Officer, Dan Lane, should attempt to put all BASEM members with email on a group list in order that they can communicate more readily on both clinical and non-clinical matters. It will not mean that members will receive hundreds of irrelevant emails, but it will enable vastly improved communication throughout the Association.

If you would like to join the list, please forward your email address to Dan Lane (danclane@aol.com). 


\section{Expression of concern about content of which Dr Paul McCrory is a single author}

This paper is authored by Dr Paul McCrory. During 2021 and 2022 there was an investigation by BJSM and BMJ which found that some of his work was the product of publication misconduct. Such misconduct includes plagiarism, duplicate publication, misquotation and misrepresentation in publications in respect of which he was listed as the sole author. ${ }^{1}$ We are placing a notice to readers on all content in relation to which he is identified as the sole author to alert them to the conclusions of our investigation.

(C) Author(s) (or their employer(s)) 2022. No commercial re-use. See rights and permissions. Published by BMJ.

Br J Sports Med 2022;0:1. doi:10.1136/bjsports-2022-106408eoc

D) Check for updates

\section{REFERENCE}

1 Macdonald H, Ragavooloo S, Abbasi K. Update into the investigation of former BJSM editor-in-chief Paul McCrory. Br I Sports Med 2022. 